\title{
Biological Monitoring and Health Assessment of 21 Metal(loid)s in Children and Adolescents in Liuzhou City, Southwest China
}

\author{
Yaping Li \\ Huazhong University of Science and Technology Tongji Medical College \\ Yu Zhang \\ Liuzhou Maternity and Child Healthcare Hospital \\ Meng Yu \\ Huazhong University of Science and Technology Tongji Medical College \\ Liqin $\mathrm{Hu}$ \\ Huazhong University of Science and Technology Tongji Medical College \\ Ting Zeng \\ Maternity and Children Hospital \\ Ling Liu \\ Huazhong University of Science and Technology Tongji Medical College \\ Limei Wang \\ Huazhong University of Science and Technology Tongji Medical College \\ Liangqiong Deng \\ Liuzhou Maternity and Child Healthcare Hospital \\ Xiang Li \\ Huazhong University of Science and Technology Tongji Medical College \\ Ping Liu \\ Liuzhou Maternity and Child Healthcare Hospital \\ Dingyuan Zeng \\ Liuzhou Maternity and Child Healthcare Hospital \\ Surong Mei ( $\nabla$ surongmei@hust.edu.cn ) \\ Huazhong University of Science and Technology Tongji Medical College
}

\section{Research Article}

Keywords: Metal(loid)s, Biomonitoring, Children and adolescents, Urine, Predictors, Health assessment

Posted Date: June 18th, 2021

DOl: https://doi.org/10.21203/rs.3.rs-574025/v1

License: @ (i) This work is licensed under a Creative Commons Attribution 4.0 International License. Read Full License

Version of Record: A version of this preprint was published at Environmental Science and Pollution Research on October 25th, 2021. See the published version at https://doi.org/10.1007/s11356-021-16953-1. 


\section{Abstract}

The concentrations of 21 metal(loid)s were analyzed in 2,050 children and adolescents aged 6-18 years from Liuzhou City, Southwest China. The detection rates of elements were all above $99 \%$. The potential contribution of demographic and dietary habits to urinary metal(loid) levels was analyzed. We found that age was an important predictor for most elements, and that children exhibited higher metal(loid) exposure levels than adolescents, expect for $\mathrm{Sr}(P<0.05)$. Urinary metal(loid) levels were higher in girls for 13 elements. Multiple regression models also showed that dietary habits may affect the distributions of metal(loid)s. This raised health concerns that the hazard quotient (HQ) of cadmium was $>1$ at the P95 value and that the risk of the mixed effect of Cd, $\mathrm{Hg}$ and TI was not negligible. The results of this study provide basic data on the reference values of urinary metal(loid) levels and health risk assessments of children and adolescents in industrial areas.

\section{Introduction}

Metal(loid)s are ubiquitous, existing widely in the surrounding air, drinking water and food encountered in daily life, and they enter the human body through the respiratory tract, digestive tract, or dermal absorption (Nordberg et al. 2014). Many metals are crucial for the normal growth of the human body in trace amounts, but can be harmful in inappropriate intake. Other metals, including some metalloids and most heavy metals, lead to toxicity with adverse health consequences. Daily exposure to contaminated food causes some metal(loid)s to accumulate in the body, and long-term accumulation can cause adverse effects on human health (Rocha et al. 2016). There have been studies shown that these metal(loid)s can have serious effects on some organ systems, such as the central nervous system, cardiovascular system, hematopoietic system and gastrointestinal tract (Diyabalanage et al. 2017, Health et al. 2009). The nature and severity of metal(loid) toxicity depend on exposure levels, chemical properties, exposure pathways and modes, and the sex and age of exposed individuals (Tchounwou et al. 2012). Children and adolescents are particularly susceptible to toxic metal(loid) exposure because of the fragility of the developing nervous system (Sughis et al. 2014). Additionally, they are more susceptible to environmental pollutants than adults because they exhibit higher rates of intestinal absorption and lower rates of renal excretion than adults (IImiawati et al. 2015). In addition, the differences between children and adults in body surface area and nutrition were both important factors (Molina-Villalba et al. 2015).

There have been studies on the biomonitoring of elements among children and adolescents. The US reported 14 urinary metals for approximately 788 children and adolescents aged 6-19 years (CDC 2015). The German Environmental Survey (GerES III) evaluated the concentrations for arsenic, cadmium, lead, and mercury in urine from approximately 1800 children aged 3-14 years (2003-2006) (Schulz et al. 2009). One study assessed 20 urinary metal(loid)s from 125 children aged between 6 and 11 years in Spain (Roca et al. 2016). Lewis et al. evaluated the concentrations of 10 elements from children aged $8-14$ years in Mexico City (Lewis et al. 2018). Zhang et al. monitored 9 urinary metal(loid)s in Chinese children aged 2-12 years and analyzed the predictors of age, sex and body mass index (Zhang et al. 2017). These biomonitoring studies from different countries investigated a variety of influencing factors, including diet, lifestyle, and geographical characteristics. The sample size was relatively small in each of these studies, and the demographic characteristics varied from region to region; therefore, further research is required to explore the relationships of metal(loid)s with demographic characteristics and dietary habits.

Liuzhou is the second largest industrial city in Guangxi Province of Southwest China, with a large population and a strong economic situation. It has a population of 1.6 million and includes more than 3,400 companies and 11 large state-owned enterprises (Miao et al. 2018). The expansion of industry, increases in population, the growth of transport networks, and increases in vehicle emissions are all potential sources of metal pollution. One study showed higher mortality rates in industrial areas, which urged us to pay more attention to the adverse impacts of metal exposure (Benach et al. 2004). The biomonitoring of metal(loid)s has become an important way to assess environmental pollutants in the general population. To the best of our knowledge, no biomonitoring data have been established regarding the reference concentration ranges of urinary metal(loid)s in this representative city of Southwest China. In this study, we collected urine samples from 2,050 children and adolescents in Liuzhou City and measured the concentrations of elements by inductively coupled plasma mass spectrometry (ICP-MS). In addition, we identified possible predictors of these pollutants and assessed their potential risks to human health. This study provides basic data for public health policies.

\section{Materials And Methods}

\subsection{Design and study population}

We adopted baseline data from a cross-sectional study conducted from February 2018 to July 2018 in Liuzhou City (southwestern China). Schools in the four districts of Liuzhou City (Cheng-zhong District, Yu-feng District, Liu-nan District and Liu-bei District), including grades 1-12, were selected (Fig. 1). Trained interviewers provided each subject with questionnaires through a face-to-face interview, and the questionnaires including demographic and dietary habits were applied to the mother, father or guardian to obtain information. Data were collected on age, sex, maternal education, passive smoking and the consumption frequency of selected foods (including milk, eggs, fish, meat, vegetable and fruits). All participants were selected randomly but required to had been living for at least one year continuously in good health in any of the study areas. A total of 2050 children and adolescents aged 6-18 years who were eligible and provided spot urine samples. All participants and parents/guardians of the children provided informed consent, and the study protocol was approved by the Ethics Committee of Tongji Medical College, Huazhong University of Science and Technology.

\subsection{Sample collection and detection}

Spot urine samples were collected into tubes by students themselves and then transported to the laboratory and stored at $-20^{\circ} \mathrm{C}$. Before testing, frozen urine samples were thawed at room temperature $\left(22 \pm 2.0^{\circ} \mathrm{C}\right)$ and centrifuged. A $0.5 \mathrm{ml}$ urine sample was transferred to a $10 \mathrm{ml}$ pre-cleaned digestion tube, and 20 $\mu \mathrm{l}$ of ultrapure nitric acid (Fisher Chemical, 67-70\%, ppt) was added and then placed in a $4^{\circ} \mathrm{C}$ refrigerator for overnight acidification. After that, the samples were balanced at room temperature for $30 \mathrm{~min}$, and $4.48 \mathrm{ml}$ of $1 \%$ nitric acid was added to dilute the urine sample, which was subsequently mixed via ultrasonication for $30 \mathrm{~min}$. 
We measured the concentrations of urinary metal(loid)s using previously published methods with some modifications (Heitland \&Köster 2006). ICP-MS (Agilent 7700, Agilent Technologies, Santa Clara, CA, USA) was used to measure the concentrations. The operation conditions for ICP-MS were as follows: plasma gas flow $15.00 \mathrm{~L} / \mathrm{min}$, auxiliary gas flow $0.8 \mathrm{~L} / \mathrm{min}$, carrier gas flow $0.8 \mathrm{~L} / \mathrm{min}$, increase in the quantity of samples of $0.4 \mathrm{~mL} / \mathrm{min}$, and unimodal residence time of $0.1 \mathrm{~s}$. Twenty-one elements were analyzed, including aluminum (Al), vanadium (V), chromium (Cr), manganese (Mn), iron (Fe), cobalt (Co), nickel (Ni), copper (Cu), zinc (Zn), arsenic (As), selenium (Se), rubidium (Rb), strontium (Sr), silver (Ag), cadmium (Cd), cesium (Cs), barium (Ba), mercury (Hg), thallium $(\mathrm{TI})$, lead $(\mathrm{Pb})$ and uranium $(\mathrm{U})$.

\subsection{Quality control}

In this experiment, the SRM1640A quality control reagent was determined after every 20 samples (the number of repetitions was 6). SRM1640A provides a confirmed urinary metal concentration, which can be considered for quality control if the measured metal concentration is consistent with the given reference value. The limits of detection (LOD) for the urinary metals were in the range $0.0001-0.2546 \mu \mathrm{g} / \mathrm{L}$. The spike recoveries of the 21 metals were in the range of 78.3-113.2\%.

The metal(loid) concentrations were corrected in relation to urine creatinine, using a creatinine assay kit and a corresponding biochemical analyzer (Mindray BS-200 CREA Kit, Mindray Biomedical Electronics Co., Ltd., Shenzhen, China) were used for detection. The corrected concentrations were in units of $\mu \mathrm{g} / \mathrm{g}$ creatinine.

\subsection{Exposure assessment and risk calculation}

The hazard quotients ( $\mathrm{HQ}$ ) were calculated as the ratio of the metal(loid) concentrations to the chemical-specific value of the biomonitoring equivalent (BE) or human biological monitoring (HBM) for noncancer endpoints. The HQ is defined as follows:

$\mathrm{HQ}=\frac{[\mathrm{Metal}(\mathrm{loid})]}{\mathrm{BE} / \mathrm{HBM}}$

Where metal(loid) is the value of P50 or P95 for urinary metal(loid)s observed in the population, and HBM is an effective tool to assess the actual dose absorbed in the environment (internal exposure dose) by measuring element levels of reactive chemicals or their metabolites in biological substrates (blood, urine and breast milk) (Schulz et al. 2011). The values of HBM-I (control level) and HBM-II (action level) determined by the HBM committee of Germany include cadmium, mercury, and thallium (Apel et al. 2017). BE is defined as the concentration of elements in the biological matrix, which is consistent with the reference dose (RfD) established by the US Environmental Protection Agency (EPA) and used in urine for cadmium (the only metal available) (Bocca et al. 2016). If the $\mathrm{HQ}$ value was $>1$, exposure to metals at or above the current exposure guidelines may have adverse health effects.

The hazard index $(\mathrm{HI})$ assesses the overall potential risk of noncarcinogenic effects of multiple elements (Saha \&Zaman 2013). The formula for HI is as follows:

$\mathrm{HI}=\sum_{i=1}^{n} \mathrm{HQ}$

$\mathrm{HI}>1$ indicates an unacceptable risk of noncarcinogenic effects in a health assessment, while $\mathrm{HI}<1$ shows an acceptable risk.

\subsection{Statistical analysis}

Statistical analysis was performed using SPSS version 25.0 and R software (Version 3.6.1, R foundation for Statistical Computing, Vienna, Austria). Geometric means (GM) and medians were calculated for descriptive statistical analysis. Levels below the LOD were allocated as the square root of LOD values over 2 (Health et al. 2009). In addition, Spearman's test was used to study correlations among metal(loid)s.

The concentrations of metal(loid)s are not normally distributed; hence, nonparametric tests, including Mann-Whitney and Kruskal-Wallis tests, were used to assess the differences in element levels and the potential effects of confounding factors (sex, maternal education, passive smoking and dietary habits). Predictor variables of interest were selected according to the results of the univariate analysis $(P<0.2)$, as well as those identified in previous studies. Accordingly, the multivariate analyses were adjusted for the following independent variables: a) demographic factors (age, sex, maternal education, passive smoking) and b) diet (frequency of milk, egg, fish, meat, vegetable and fruits intake).

The multivariate linear regression model was used to evaluate the relationship between the concentration of metal(loid)s corrected for natural logarithmic transformation and factors with a significance level of $P<0.05$. The models were built following a forward stepwise variable selection procedure. Residual analysis was used to test the independence, normality and homogeneity of variance once the model was established. The regression coefficients and confidence levels at $95 \%$ significance were calculated for the multivariate models.

\section{Results}

A total of 2050 students (1016 boys and 1034 girls) were included in this research. Information about the demographic characteristics and dietary intake habits of the participants was shown in Table 1. The students' ages ranged from 6 to 18 years, and $54.0 \%$ of mothers had an education level below high school. 
Table 1

Characteristics of the study population from Liuzhou City,

Southwest China $(n=2050)$.

\begin{tabular}{|c|c|c|}
\hline Variable & Category & $N(\%)$ \\
\hline \multirow[t]{2}{*}{ Sex } & Boys & $1016(49.6)$ \\
\hline & Girls & $1034(50.4)$ \\
\hline \multirow[t]{2}{*}{ Maternal education levels } & $\leq 9$ years & $1106(54.0)$ \\
\hline & $>9$ years & $944(46.0)$ \\
\hline \multirow[t]{3}{*}{ Passive smoking } & No & $1539(75.1)$ \\
\hline & Yes & $475(23.2)$ \\
\hline & Missing & $36(1.8)$ \\
\hline \multirow[t]{3}{*}{ Milk frequency intake } & $<5$ times/week & $1028(50.1)$ \\
\hline & $\geq 5$ times/week & $896(43.7)$ \\
\hline & Missing & $126(6.1)$ \\
\hline \multirow[t]{3}{*}{ Egg frequency intake } & $\leq 2$ times/week & $971(47.4)$ \\
\hline & $>2$ times/week & $959(46.8)$ \\
\hline & Missing & $120(5.9)$ \\
\hline \multirow[t]{3}{*}{ Fish frequency intake } & $<1$ time/week & $719(35.1)$ \\
\hline & $\geq 1$ time/week & $1214(59.2)$ \\
\hline & Missing & $117(5.7)$ \\
\hline \multirow[t]{3}{*}{ Meat frequency intake } & $\leq 3$ times/week & $912(44.5)$ \\
\hline & $>3$ times/week & $1026(50.0)$ \\
\hline & Missing & $112(5.5)$ \\
\hline \multirow[t]{3}{*}{ Vegetable frequency intake } & $\leq 5$ times/week & $848(41.4)$ \\
\hline & $>5$ times/week & $1064(51.9)$ \\
\hline & Missing & $138(6.7)$ \\
\hline \multirow[t]{3}{*}{ Fruits frequency intake } & $<5$ times/week & $1011(49.3)$ \\
\hline & $\geq 5$ times/week & $911(44.4)$ \\
\hline & Missing & $128(6.2)$ \\
\hline
\end{tabular}

\subsection{The concentrations and correlations of metal(loid)s}

The distribution of metal(loid) concentrations in the urine of the study population was presented in Table 2 (in $\mu \mathrm{g} / \mathrm{L}$ and $\mu \mathrm{g} / \mathrm{g}$ creatinine). Median and geometric means were provided for each element. The detection frequencies (DFs) were all above $99 \%$. Fig. S1 showed the Spearman correlations between urinary metal(loid)s when using GM concentrations, and significant positive correlations were found among most metal(loid)s $(P<0.05)$. There were some strong correlations [ $\mathrm{r}=0.78$ ( $\mathrm{Al}$ and $\mathrm{Mn}), 0.87$ (Rb and $\mathrm{Cs}$ ), 0.80 ( $\mathrm{Mn}$ and $\mathrm{Ba}), 0.79$ (Rb and TI)]. The correlations between cadmium and other metal(loid)s were generally weak or moderate ( $r$ below 0.5 ). 
Table 2

Unadjusted, creatine ( $\mathrm{Cr}$ )-adjusted concentrations of urinary metal(loid)s from children and adolescents in Liuzhou City, Southwest China.

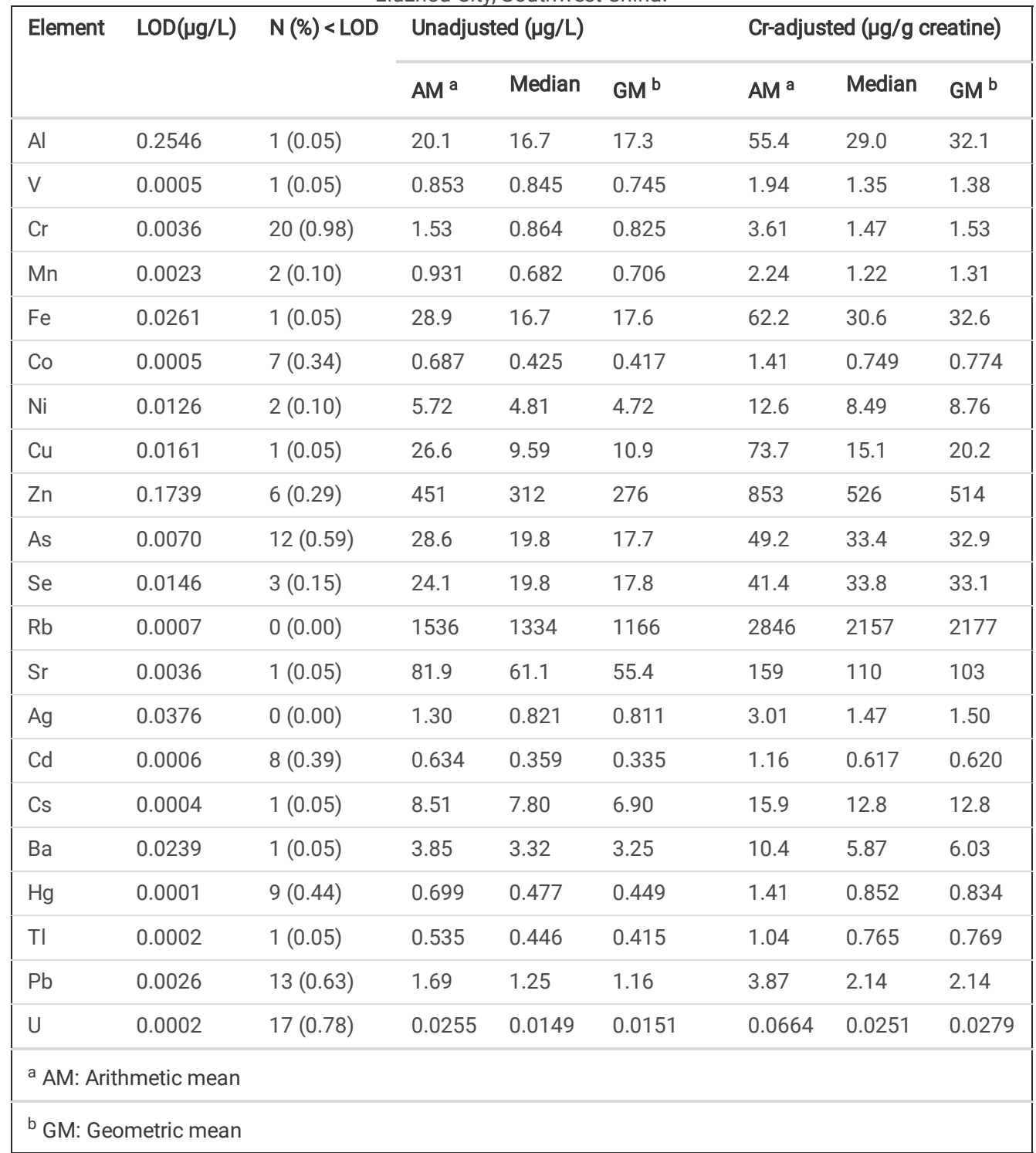


Table 3

Median and geometric mean concentrations of urinary metal(loid)s among different regions.

\begin{tabular}{|c|c|c|c|c|c|c|c|c|c|c|c|c|c|c|c|c|}
\hline \multirow[t]{2}{*}{ Reference } & \multirow[t]{2}{*}{ Site } & \multirow[t]{2}{*}{ Age } & \multirow[t]{2}{*}{ Number } & \multirow[t]{2}{*}{ Value } & \multicolumn{12}{|c|}{ Concentration } \\
\hline & & & & & Al & V & $\mathrm{Cr}$ & Mn & Co & $\mathrm{Ni}$ & $\mathrm{Cu}$ & $\mathrm{Zn}$ & As & $\mathrm{Se}$ & Cd & C \\
\hline \multirow{2}{*}{$\begin{array}{l}\text { Present } \\
\text { study }\end{array}$} & \multirow[t]{2}{*}{ China } & \multirow{2}{*}{$\begin{array}{l}6- \\
18\end{array}$} & \multirow[t]{2}{*}{2050} & $\mathrm{GM}^{\mathrm{a}}$ & 32.1 & 1.38 & 1.53 & 1.31 & 0.774 & 8.76 & 20.2 & 514 & 32.9 & 33.1 & 0.620 & 1 \\
\hline & & & & $\begin{array}{l}\text { Median } \\
\mathrm{a}\end{array}$ & 29.0 & 1.35 & 1.47 & 1.22 & 0.749 & 8.49 & 15.1 & 526 & 33.4 & 33.8 & 0.617 & 1 \\
\hline $\begin{array}{l}\text { (Zhang et } \\
\text { al. 2017) }\end{array}$ & China & $\begin{array}{l}2- \\
12\end{array}$ & 210 & $\begin{array}{l}\text { Median } \\
\mathrm{a}\end{array}$ & 358.67 & 1.79 & & 6.37 & & & & & 12.21 & & & \\
\hline \multirow{2}{*}{$\begin{array}{l}\text { (Zhang et } \\
\text { al. 2019) }\end{array}$} & \multirow[t]{2}{*}{ China } & $3-4$ & 55 & \multirow{2}{*}{$\begin{array}{l}\text { Median } \\
\mathrm{a}\end{array}$} & & & 4.59 & 44.43 & 0.72 & & 14.05 & 516.6 & 13.09 & & \multirow[t]{2}{*}{0.18} & \\
\hline & & $\begin{array}{l}10- \\
13\end{array}$ & & & & & & & & & & & & & & \\
\hline $\begin{array}{l}\text { (Feng et } \\
\text { al. 2015) }\end{array}$ & China & $\begin{array}{l}18- \\
80\end{array}$ & 2004 & $\mathrm{GM}^{\mathrm{b}}$ & 33.80 & 0.51 & 1.45 & 2.56 & 0.27 & 2.36 & 7.70 & 276.9 & 28.02 & 7.28 & 0.87 & \\
\hline $\begin{array}{l}\text { (Roca et } \\
\text { al. 2016) }\end{array}$ & Spain & $\begin{array}{l}6- \\
11\end{array}$ & 125 & $\mathrm{GM}^{\mathrm{a}}$ & & 0.223 & & 0.430 & 1.41 & 4.27 & 35.0 & 515 & 33.3 & 55.7 & 0.176 & 5 \\
\hline $\begin{array}{l}\text { (Molina- } \\
\text { Villalba et } \\
\text { al. 2015) }\end{array}$ & Spain & $\begin{array}{l}6- \\
11\end{array}$ & 261 & $\mathrm{GM}^{\mathrm{a}}$ & & & & 0.42 & & & & & 2.438 & & 0.747 & \\
\hline $\begin{array}{l}\text { (Aguilera } \\
\text { et al. } \\
2010 \text { ) }\end{array}$ & Spain & $\begin{array}{l}5- \\
17\end{array}$ & 196 & $\mathrm{GM}^{\mathrm{a}}$ & & & 0.43 & & & 1.61 & 11.46 & & 1.6 & & 0.41 & \\
\hline $\begin{array}{l}\text { (CDC } \\
2015)\end{array}$ & $\begin{array}{l}\text { United } \\
\text { States }\end{array}$ & $\geq 6$ & 2502 & $\mathrm{GM}^{\mathrm{a}}$ & & & & 0.140 & 0.370 & & & & 7.77 & & 0.176 & 4 \\
\hline $\begin{array}{l}\text { (Health } \\
\text { \&Services } \\
2018 \text { ) }\end{array}$ & $\begin{array}{l}\text { United } \\
\text { States }\end{array}$ & & & $\mathrm{GM}^{\mathrm{b}}$ & & & & 0.123 & 0.391 & & & & 8.63 & & 0.124 & \\
\hline $\begin{array}{l}\text { (Haines } \\
\text { et al. } \\
\text { 2017) }\end{array}$ & Canada & $\begin{array}{l}6- \\
79\end{array}$ & & $\mathrm{GM}^{\mathrm{b}}$ & & & & 0.081 & 0.23 & 1.1 & 9.0 & 250 & 12 & 49 & 0.34 & 4 \\
\hline $\begin{array}{l}\text { (Schulz et } \\
\text { al. 2009) }\end{array}$ & Germany & $\begin{array}{l}3- \\
14\end{array}$ & 1790 & $\mathrm{GM}^{\mathrm{b}}$ & & & & & & 1.26 & & & 4.40 & & 0.068 & \\
\hline $\begin{array}{l}\text { (Nisse et } \\
\text { al. 2017) }\end{array}$ & France & $\begin{array}{l}20- \\
59\end{array}$ & 1910 & $\mathrm{GM}^{\mathrm{a}}$ & 1.61 & 0.21 & 0.33 & 0.24 & 0.53 & 1.75 & & 278 & 16.1 & & 0.33 & \\
\hline $\begin{array}{l}\text { (Hoet et } \\
\text { al. 2013) }\end{array}$ & Belgium & $\begin{array}{l}18- \\
80\end{array}$ & 1022 & $\mathrm{GM}^{\mathrm{a}}$ & 2.03 & 0.223 & 0.101 & & 0.150 & 1.73 & 6.94 & 229 & & 21.3 & 0.228 & \\
\hline $\begin{array}{l}\text { (Santos } \\
\text { et al. } \\
\text { 2018) }\end{array}$ & Brazil & $\begin{array}{l}6- \\
11\end{array}$ & 96 & $\mathrm{GM}^{\mathrm{b}}$ & & & & 0.8 & & & 6.9 & 509.4 & & 10.0 & & \\
\hline $\begin{array}{l}\text { (Godebo } \\
\text { et al. } \\
2019 \text { ) }\end{array}$ & Ethiopian & $\begin{array}{l}10- \\
50\end{array}$ & 386 & $\mathrm{GM}^{\mathrm{b}}$ & 25.0 & & & & 1.05 & 6.95 & 5.21 & 283 & 20.9 & & 0.61 & \\
\hline $\begin{array}{l}\text { (Lewis et } \\
\text { al. 2018) }\end{array}$ & Mexico & $\begin{array}{l}8- \\
14\end{array}$ & 250 & $\mathrm{GM}^{\mathrm{b}}$ & 17.7 & & & 1.26 & 0.80 & 9.27 & & 408 & 15.5 & & 0.14 & \\
\hline $\begin{array}{l}\text { (Aprea et } \\
\text { al. 2018) }\end{array}$ & Italy & $\begin{array}{l}18- \\
60\end{array}$ & 260 & $\mathrm{GM}^{\mathrm{a}}$ & & 0.099 & 0.218 & 0.298 & 0.420 & 1.48 & 11.5 & & & & 0.255 & \\
\hline $\begin{array}{l}\text { (Park et } \\
\text { al. 2016) }\end{array}$ & $\begin{array}{l}\text { South } \\
\text { korea }\end{array}$ & $>19$ & 6311 & $\mathrm{GM}^{\mathrm{b}}$ & & & & & & & & & 35.0 & & 0.58 & \\
\hline \multicolumn{16}{|c|}{${ }^{a} \mu \mathrm{g} / \mathrm{g}$ creatinine } & \\
\hline
\end{tabular}

\subsection{Predictors of metal(loid)s}

The urinary concentrations of metal(loid)s and their relationships with the main characteristics and dietary habits of the study population were shown in Table S1. Table S2 showed the multivariate log-linear regression analysis of element levels in urine with influencing factors. Figure 2 presented coefficient of the multivariate log-linear regression and corresponding 95\% confidence intervals (Cls).

By using the regression models presented in Fig. 2, we found that age was an important predictor of element levels and that children exhibited higher metal(loid) exposure levels than adolescents, expect for Sr. The concentrations of 13 elements (Al, $\mathrm{V}, \mathrm{Cr}, \mathrm{Mn}, \mathrm{Fe}, \mathrm{Co}, \mathrm{Ni}, \mathrm{Rb}, \mathrm{Sr}, \mathrm{Ba}$, TI, Pb and U) were higher in 
girls $(P<0.05)$. Concerning maternal education level, two different tendencies were noticed: the levels of $\mathrm{Co}$, $\mathrm{Sr}$, $\mathrm{Cd}$ and $\mathrm{Pb}$ in urine were lower in the more educated group, but the opposite occurred in the case of $\mathrm{Cr}$ and Se. The concentrations of $\mathrm{Cr}$, $\mathrm{Co}$ and $\mathrm{Ni}$ in passive smokers were higher and of statistical significance $(P<0.05)$.

Regarding the association with dietary intake habits, significant relationships were found between vegetable intake and $\mathrm{Al}, \mathrm{Cr}$, Mn, $\mathrm{Fe}, \mathrm{Ni}, \mathrm{Zn}, \mathrm{Se}, \mathrm{Cs}$, Ba and $\mathrm{Tl}$, which showed higher concentrations in students who ate more vegetable. The same effect was observed between the consumption of fish and As, Se, Rb and Tl. Meat was also associated with significantly higher $\mathrm{Zn}$ and $\mathrm{Hg}$. Milk consumption was negatively associated with $\mathrm{V}, \mathrm{Co}, \mathrm{Ag}, \mathrm{Cd}$ and $\mathrm{Tl}$.

\subsection{Risk assessment of metal(loid) exposure}

When urinary element levels are higher than HBM-II, immediate measures should be taken to reduce exposure; when the values are higher than HBM-I, it is necessary to reduce specific exposure sources in an appropriate manner. Additionally, urinary element levels above BEs suggest that further study on the source of metal(loid) exposure is needed. Table 4 showed the human biomonitoring assessment values for cadmium, mercury, and thallium. The data indicated that $31.8 \%$ of the population had urinary cadmium levels between HBM-I and HBM-II, $1.4 \%(n=28)$ of the population had urinary cadmium levels above HBM-II and $3.4 \%$ of the population had urinary cadmium levels above BEs. Seven of the subjects had levels of mercury in their urine between HBM-I and HBM-II. Only one sample had a thallium concentration exceeding $5 \mu \mathrm{g} / \mathrm{L}$. According to previous studies, the threshold value of total arsenic is $50 \mu \mathrm{g} / \mathrm{I}(\mathrm{Caldwell}$ et al. 2009), and $11.6 \%$ of the samples exceeded this level in this study. However, the forms of arsenic are complex, and we need to further explore the associated biological factors to achieve a better understanding.

Table 4

Human biomonitoring assessment values for cadmium, mercury, and thallium.

\begin{tabular}{|c|c|c|c|c|c|}
\hline Metals & Population group & $\begin{array}{l}\text { HBM-I } \\
\text { (\% of subjects between HBM-I and HBM-II) }\end{array}$ & $\begin{array}{l}\text { HBM-II } \\
\text { (\% of subjects }>\mathrm{HBM}-\mathrm{II})\end{array}$ & $\begin{array}{l}\text { BE } \\
\text { (\% of subjects }>B E)\end{array}$ & Reference \\
\hline Cd & Children and adolescents & $0.5 \mu \mathrm{g} / \mathrm{L}(31.8 \%)$ & $2 \mu \mathrm{g} / \mathrm{L}(1.4 \%)$ & $1.5 \mu \mathrm{g} / \mathrm{L}(3.4 \%)$ & (Schulz et al. 2011) \\
\hline $\mathrm{Hg}$ & Children and adults & $7 \mu \mathrm{g} / \mathrm{L}(0.3 \%)$ & $25 \mu \mathrm{g} / \mathrm{L}(0.1 \%)$ & & (Schulz et al. 2007) \\
\hline TI & General population & $5 \mu \mathrm{g} / \mathrm{L}(0.1 \%)$ & & & (Apel et al. 2017) \\
\hline
\end{tabular}

$\mathrm{HBM}-\mathrm{I}$ and BE values are only applicable to cadmium, mercury and thallium; therefore, only the HQ values of these metals could be calculated. In this study, the HQ was used to evaluate whether children's and adolescents' exposure exceeded the exposure risk values. The HQ values of all three metals were less than 1 when using the P50 value of the population (Fig. 3). However, the HQ value of urinary cadmium alone was above 1 at the P95 value, suggesting that there may be health risks in a small number of people. When evaluating the joint effect of multiple metals, we presumed that all metals presented synergistic effects, and the $\mathrm{HI}$ was calculated from the sum of the $\mathrm{HQ}$ of each metal. The combined exposure to cadmium, mercury and thallium showed an $\mathrm{HI}$ value above 1 when the P95 value was used, while at the P50 value, the HI value was close to 1 in this study.

\section{Discussion}

This study assessed exposure to metal(loid)s among children and adolescents in Liuzhou City, Southwest China. We measured concentrations of urinary metal(loid)s and correlations among different elements. According to the World Health Organization recommendations, urine samples with creatinine values below $0.3 \mathrm{~g} / \mathrm{L}$ or above $3 \mathrm{~g} / \mathrm{L}$ were unrepresentative and they should not be included in the following statistical analysis in order to reduce the possibility of overestimation or underestimation in calculating concentrations. In our study population, 4 samples had creatinine levels above $3 \mathrm{~g} / \mathrm{L}$ and $21.5 \%$ of samples showed levels below $0.3 \mathrm{~g} / \mathrm{L}$. We performed a sensitivity analysis by removing samples with creatinine levels without in the range of $0.3 \mathrm{~g} / \mathrm{L}-3 \mathrm{~g} / \mathrm{L}$ in order to compare the coefficients of the regression models. No significant changes were observed in the regression coefficients comparing to the whole analysis that requires the conclusions of the study to be changed.

The comparison of the concentrations of urinary metal(loid)s in different regions including Europe, the USA and Canada was presented in Table 3. The concentrations in our study fell within the range of values usually reported in other studies for many metals ( $\mathrm{Al}, \mathrm{V}, \mathrm{Co}, \mathrm{Ni}, \mathrm{Cu}, \mathrm{Zn}, \mathrm{As}, \mathrm{Se}, \mathrm{Rb}, \mathrm{Sr}, \mathrm{Ag}, \mathrm{Cs}, \mathrm{Ba}, \mathrm{Hg}$, $\mathrm{U}$ ) or even lower $(\mathrm{Mn})$. We observed that the average levels of urinary metal(loid) concentrations ( $\mathrm{Cr}, \mathrm{Cd}, \mathrm{Tl}, \mathrm{Pb})$ in our study were slightly higher than those in other countries.

The $\mathrm{GM}$ of chromium found $(1.53 \mu \mathrm{g} / \mathrm{g}$ creatinine) was close to the GM of $1.57 \mu \mathrm{g} / \mathrm{g}$ creatinine in China (Xu et al. 2020) but lower than the GM of $2.15 \mu \mathrm{g} / \mathrm{g}$ creatinine in southern Brazil (Rocha et al. 2016). The level was higher than those in Spanish children aged 5-17 years (0.43 $\mu \mathrm{g} / \mathrm{g}$ creatinine) (Aguilera et al. 2010) and in French adults $(0.33 \mu \mathrm{g} / \mathrm{g}$ creatinine) (Nisse et al. 2017). Animal studies showed that chromium could enter the brain through the olfactory pathway, which had a detrimental effect on experimental ethology and memory processes and retention (Singh \&Chowdhuri 2017). Chromium in the environment mainly comes from the production of metal alloys, leathers, steel and so on (ATSDR \&asp 2012). Automobile manufacturing and steel production are major industries in Liuzhou City, and previous studies have reported high levels of chromium in the Liujiang River flowing through Liuzhou City (Miao et al. 2020). Students' chromium load level is high, which may be harmful to their health, affecting the normal growth and development of children.

Regarding cadmium levels, the GM of the student group $(0.620 \mu \mathrm{g} / \mathrm{g}$ creatinine) was higher than those found in Spain (0.41 $\mu \mathrm{g} / \mathrm{g}$ creatine) (Aguilera et al. 2010) and Japan (0.34 $\mu \mathrm{g} / \mathrm{g}$ creatine) (Ilmiawati et al. 2015), but lower than that found in the industrial area of Spain (0.75 $\mu \mathrm{g} / \mathrm{g} \mathrm{creatinine})$ (Molina-Villalba et al. 2015). Wastewater, waste gas and waste residue from industrial sites could increase the cadmium load in the local population, so the concentration of cadmium in the general population has received increasing attention worldwide. 
The GM of urinary lead concentration measured in this study was $2.14 \mu \mathrm{g} / \mathrm{g}$ creatinine, higher than that in Spain (1.16 $\mu \mathrm{g} / \mathrm{g}$ creatinine) (Roca et al. 2016) and similar to that in industrial areas of Spain ( $2.22 \mu \mathrm{g} / \mathrm{g}$ creatinine) (Molina-Villalba et al. 2015). In addition, the urinary lead level in our study was higher than that of adults reported in rural areas along the Yangtze River $(1.51 \mu \mathrm{g} / \mathrm{g}$ creatinine) (Cui et al. 2017). Lead could hinder the absorption of trace elements in the human body and affect growth and development; long-term exposure to low doses of lead could also cause immune disorders and changes in host resistance (Fleisch et al. 2013). Lead is considered to represent pollution from vehicles, which often occurs in traffic areas (Zhou et al. 2016). Liuzhou is one of the five major motor cities in China. Although leaded gasoline has been phased out in China since 2001, other agents in unleaded gasoline could still introduce a certain amount of lead into the atmosphere, especially in areas where there are more gasoline-based motor vehicles and motorcycles on (Li et al. 2012). In addition, population growth and industrial expansion are potential sources of lead pollution that may contribute to the increased concentration of urinary lead.

Manganese is an element that is closely related to human health; either its excess or deficiency can lead to disease, and low levels of manganese can adversely affect neurodevelopmental outcomes (Riojas-Rodríguez et al. 2010). Our study showed that the GM of manganese (1.31 $\mu \mathrm{g} / \mathrm{g}$ creatinine) was higher than that in Spain $(0.48 \mu \mathrm{g} / \mathrm{g}$ creatinine) (Perez et al. 2018), but lower than those reported in Italy $(7.52 \mu \mathrm{g} / \mathrm{g}$ creatinine) (Pino et al. 2012) and the industrial area of China $(6.37 \mu \mathrm{g} / \mathrm{g}$ creatinine) (Zhang et al. 2017). Urinary concentrations in the range of $1 \mu \mathrm{g} / \mathrm{L}$ to $8 \mu \mathrm{g} / \mathrm{L}$ are considered to fall within the reference range; only 6 individual urine samples had manganese concentrations exceeding $8 \mu \mathrm{g} / \mathrm{L}$, while more than $40 \%$ of individuals had urinary manganese concentrations below $1 \mu \mathrm{g} / \mathrm{L}$ (Godebo et al. 2019).

Urinary concentrations of cobalt, nickel and barium were comparable to those found in Mexican children aged $8-14$ years $(0.8 \mu \mathrm{g} / \mathrm{L}, 9.27 \mu \mathrm{g} / \mathrm{L}$ and $3.09 \mu \mathrm{g} / \mathrm{L}$, respectively) (Lewis et al. 2018) and were slightly higher than the concentrations in Belgian adults $(0.15 \mu \mathrm{g} / \mathrm{g}$ creatinine, $1.73 \mu \mathrm{g} / \mathrm{g}$ creatinine and $1.68 \mu \mathrm{g} / \mathrm{g}$ creatinine, respectively) (Hoet et al. 2013). Zinc and mercury concentrations were comparable to those of Spanish children aged 6-11 years (515 $\mu$ g/g creatinine and $0.73 \mu \mathrm{g} / \mathrm{g}$ creatinine) (Molina-Villalba et al. 2015). The concentration of thallium was higher than that in several other countries (CDC 2015, Roca et al. 2016). Current studies of the health effects of TI are limited, but they may be related to headache, anorexia, arm, thigh and abdominal pain (Peter \&Viraraghavan 2005). The high levels of some elements may occur because Liuzhou City has a large number of factories. Industrial pollution is a major potential source of metal exposure and may also be a source of surrounding bioavailable metal(loid)s, making metal(loid)s more accessible to humans through water, food, and air particles.

According to the obtained Spearman matrix in Fig. S1, significant correlations were observed between almost all metal(loid)s, suggesting possible similar sources. The relationship between $\mathrm{Mn}$ and $\mathrm{Cu}(r=0.47)$ and $\mathrm{Hg}$ and $\mathrm{Se}(r=0.44)$ in our study were similar to those reported among Spanish children (Roca et al. 2016). Moderate to strong relationships were found between urinary Al and Cd $(r=0.38)$ and As and Se $(r=0.66)$. Lewis et al. also observed a moderate relationship between urinary Al and Cd $(r=0.38)$ in Mexican children (Lewis et al. 2018).

Regarding predictors of exposure to metal(loid)s, we found that age was an important predictor of element levels and that children exhibited higher metal(loid) exposure levels than adolescents, expect for Sr. Previous reports also found that older people present lower levels of metal(loid)s (Godebo et al. 2019, Rocha et al. 2016). Other studies also showed that children's age was the one of the most important predictors among most metal(loid)s, possibly because younger children were more exposed to external substances through hand-to-mouth activity (Roca et al. 2016). It is also possible that the metabolism functions of elements in the lower age groups have not reached optimal levels, which increases the element levels in urine.

Taking sex into account, most urinary element levels were higher in girls, among which the differences in the concentrations of 13 elements were significant $(P<0.05)$. This finding may be explained by the fact that girls were more exposed to metal(loid)s in beauty products such as nail polish and hand cream. Continued use of these products increases the absorption of metal(loid)s, which is particularly harmful to children. In addition, high concentrations of lead and cadmium were found in white cosmetics such as creams and lotions (Orisakwe \&Otaraku 2013). In relation to maternal education, children whose mothers reported higher education levels showed lower concentrations of $\mathrm{Co}, \mathrm{Sr}, \mathrm{Cd}$ and $\mathrm{Pb}$, while a positive correlation was found in the levels of $\mathrm{Cr}$ and $\mathrm{Se}$. This finding may be due to the association between family status and other variables potentially associated with exposure to metal(loid)s. The concentrations of $\mathrm{Cr}$, $\mathrm{Co}$ and $\mathrm{Ni}$ in passive smokers were higher and of statistical significance $(P<0.05)$. Many metals found in cigarette smoke, tobacco, and cigarette paper, such as $\mathrm{Cr}, \mathrm{Ni}, \mathrm{Cu}, \mathrm{Cd}$, and $\mathrm{Pb}$, are potential health threats(Bernhard et al. 2005). Our research also showed the passive-smoking group had higher levels of urinary cadmium, although no significant association with urinary cadmium levels and passive smoking was found. Smoking by family members is more likely to be inhaled by student groups in an indoor environment with poor ventilation, and attention should be given to passive smoking in children in this region.

Dietary habits may also affect the distribution of various metal(loid)s. Milk, vegetable and fish were important factors in assessing the source of metal(loid) exposure in our study. People who ate fish, the main dietary source of arsenic, showed higher levels of arsenic in their urine. Other studies observed that increasing arsenic levels were related to frequent consumption of fish (Bocca et al. 2016, Schulz et al. 2011). Studies showed a significant correlation between urinary arsenic concentrations and total protein intake, and fish are rich in protein (Kordas et al. 2016). People with higher dairy intake had lower urinary levels of V, Co, Ag, Cd and Tl, as in previous studies (Ashrap et al. 2020, Roca et al. 2016). Regarding Cd, these results may be related to the inverse ratio between the presence of large amounts of minerals (such as $\mathrm{Ca}$ ) in dairy products and the absorption of Cd, as previously reported (Castaño et al. 2012). People who ate more vegetables had higher levels of $\mathrm{Al}, \mathrm{Cr}, \mathrm{Mn}, \mathrm{Zn}, \mathrm{Rb}, \mathrm{Cs}, \mathrm{Ba}$ and $\mathrm{Tl}$ in their urine. Vegetables are an important part of people's diet and contain some essential trace elements but may also contain heavy metal residues (Zeinali et al. 2019). People who ate more meat had higher levels of zinc in their urine. Due to lifestyle changes and increased demand for fast food based on meat, meat consumption has increased in recent years. Eating food containing metal residues may lead to neurological problems, headaches and liver dysfunction (Farmer et al. 2011). Although this work was a cross-sectional study, the participants' food intake and urine metal content remained in long-term equilibrium, thus indicating the potential role of food in metal(loid) exposure.

In terms of the risk of metals, $31.8 \%$ of the population had urinary cadmium levels between HBM-I and HBM-II levels, and only the HQ of cadmium was $>1$ at the P95 value, indicating that exposure to this metal may pose a health risk to a small number of people. Similar tendencies were found in a previous 
biomonitoring study carried out in Italy (Bocca et al. 2016). Another study of wild fish in the Liujiang River also found that the potential health risks were mainly caused by the presence of $\mathrm{Cr}$ and $\mathrm{Cd}$ (Miao et al. 2020). The $\mathrm{HI}$ of multiple metals was near 1 at the P50 value and above 1 at the P95 values, indicating that the joint toxicity of multiple metals could not be ignored and that noncancer health consequences are likely to occur in children and adolescents exposed to metals in the assessed areas. However, this algorithm may be affected by many parameters. The mechanism of action and toxic effects of these metals in the human body may not be the same, and there may be antagonistic or synergistic effects among them. More data, including information on socioeconomic, personal care products, and environmental conditions, are essential to determine the real effect of metal exposure.

\section{Strengths And Limitations}

This is the first study to provide valuable information on metal exposure in Liuzhou City, Southwest China, based on a large sample size. This study also provided information on potential predictors, including sociodemographic and dietary habits. However, our study also has some limitations. First, urinary metal levels were only measured at one spot time. Urine is the preferred matrix in metal biomonitoring, and previous studies showed that spot urine could reflect both short- and long-term exposure to metals in situations with similar lifestyles. Second, the amount of dietary intake was not included in the questionnaire in detail, and we were unable to assess the effect of unmeasured confusing information. Third, the area is historically industrial and we could not ignore the metal exposure from particulate matter, dust, and drinking water. In the future, studies should be designed to collect more detailed and comprehensive questionnaire information, duplicate biological samples to explain exposure levels in children and adolescents.

\section{Conclusion}

In the present study, we evaluated 21 urinary metal(loid) concentrations in children and adolescents in Liuzhou City, Southwest China, analyzed the potential predictors of metal(loid) exposure, and assessed the potential health risks. In general, we found that children have higher metal(loid) exposure levels than adolescents. The multiple regression models also revealed that dietary habits may affect the distributions of metal(loid)s. It is particularly noteworthy that $31.8 \%$ of the population had cadmium levels between HBM-I and HBM-II, and the potential health risks of the mixed effects of cadmium, mercury, and thallium exposure were not negligible. In the future, more comprehensive investigations are warranted in this industrial area to protect children and adolescent health.

\section{Declarations}

\section{Author contribution}

Yaping Li: conceptualization, investigation, writing original draft. Yu Zhang: investigation, validation, methodology. Meng Yu: investigation, validation, methodology. Liqin Hu: investigation, validation, methodology. Ting Zeng: investigation, validation, methodology. Ling Liu: data curation, software, validation. Limei Wang: data curation, software, validation. Liangqiong Deng: data curation, software, validation. Xiang Li: data curation, software, validation. Ping Liu: investigation, methodology, data curation. Dingyuan Zeng: project administration, resources, supervision. Surong Mei: conceptualization, funding acquisition, project administration, resources, supervision. All authors read and approved the final manuscript.

\section{Funding}

This research was funded by the National Key R\&D Program of China (2017YFC0212003) and the National Natural Science Foundation of China (No. 42077397).

\section{Availability of data and materials}

The datasets used and analyzed during the current study are available from the corresponding author on reasonable request.

Ethical approval and consent to participate Not applicable

Consent for publication Not applicable

Competing interests Not applicable

\section{References}

1. Aguilera I et al (2010) Urinary levels of arsenic and heavy metals in children and adolescents living in the industrialised area of Ria of Huelva (SW Spain). Environment international 36:563-569

2. Apel P, Angerer J, Wilhelm M, Kolossa-Gehring M (2017) New HBM values for emerging substances, inventory of reference and HBM values in force, and working principles of the German Human Biomonitoring Commission. Int J Hyg Environ Health 220:152-166

3. Aprea MC, Apostoli P, Bettinelli M, Lovreglio P, Negri S, Perbellini L, Perico A, Ricossa MC, Salamon F, Scapellato ML, lavicoli I (2018) Urinary levels of metal elements in the non-smoking general population in Italy: SIVR study 2012-2015. Toxicology letters 298:177-185

4. Ashrap P, Watkins DJ, Mukherjee B, Boss J, Richards MJ, Rosario Z, Vélez-Vega CM, Alshawabkeh A, Cordero JF, Meeker JD (2020) Predictors of urinary and blood Metal(loid) concentrations among pregnant women in Northern Puerto Rico. Environmental research 183:109178

5. ATSDR SJPHS, US Department of Health, asp HShwacgtt (2012) Toxicological Profile for Chromium. Agency for Toxic Substances and Disease Registry

6. Benach J, Yasui Y, Martínez JM, Borrell C, Pasarín MI, Daponte A (2004) The geography of the highest mortality areas in Spain: a striking cluster in the southwestern region of the country. Occup Environ Med 61:280-281 
7. Bernhard D, Rossmann A, Wick G (2005) Metals in cigarette smoke. IUBMB Life 57:805-809

8. Bocca B, Bena A, Pino A, D'Aversa J, Orengia M, Farina E, Salamina G, Procopio E, Chiusolo M, Gandini M, Cadum E, Musmeci L, Alimonti A (2016) Human biomonitoring of metals in adults living near a waste-to-energy incinerator in ante-operam phase: Focus on reference values and health-based assessments. Environmental research 148:338-350

9. Caldwell KL, Jones RL, Verdon CP, Jarrett JM, Caudill SP, Osterloh JD (2009) Levels of urinary total and speciated arsenic in the US population: National Health and Nutrition Examination Survey 2003-2004. J Expo Sci Environ Epidemiol 19:59-68

10. Castaño A, Sánchez-Rodríguez JE, Cañas A, Esteban M, Navarro C, Rodríguez-García AC, Arribas M, Díaz G, Jiménez-Guerrero JA (2012) Mercury, lead and cadmium levels in the urine of 170 Spanish adults: a pilot human biomonitoring study. Int J Hyg Environ Health 215:191-195

11. CDC (2015) Fourth National Report on Human Exposure to Environmental Chemicals, Updated Tables (February, 2015). US Department of Health and Human Services, Centers for Disease Control and \&\#8230

12. Cui Y, Zhong Q, Hu M, Sheng J, Yang Y, Liang L, Wang X, Yang Y, Zhou M, Huang F (2017) Human biomonitoring of eight trace elements in urine of residents living in rural areas along the Yangtze River, China. Environ Sci Pollut Res Int 24:27963-27973

13. Diyabalanage S, Fonseka S, Dasanayake D, Chandrajith RJJoTEiM B (2017) Environmental exposures of trace elements assessed using keratinized matrices from patients with chronic kidney diseases of uncertain etiology (CKDu) in Sri Lanka. 39, 62-70

14. Farmer JG, Broadway A, Cave MR, Wragg J, Fordyce FM, Graham MC, Ngwenya BT, Bewley RJ (2011) A lead isotopic study of the human bioaccessibility of lead in urban soils from Glasgow, Scotland. Sci Total Environ 409:4958-4965

15. Feng W, He X, Chen M, Deng S, Qiu G, Li X, Liu C, Li J, Deng Q, Huang S, Wang T, Dai X, Yang B, Yuan J, He M, Zhang X, Chen W, Kan H, Wu T (2015) Urinary metals and heart rate variability: a cross-sectional study of urban adults in Wuhan, China. Environ. Health Perspect. 123, $217-22$

16. Fleisch AF, Burns JS, Williams PL, Lee MM, Sergeyev O, Korrick SA, Hauser RJEhp (2013) Blood lead levels and serum insulin-like growth factor 1 concentrations in peripubertal boys. 121, 854-858

17. Godebo TR, Paul CJ, Jeuland MA, Tekle-Haimanot R (2019) Biomonitoring of metals and trace elements in urine of central Ethiopian populations. Int J Hyg Environ Health 222:410-418

18. Haines DA, Saravanabhavan G, Werry K, Khoury C (2017) An overview of human biomonitoring of environmental chemicals in the Canadian Health Measures Survey: 2007-2019. Int J Hyg Environ Health 220:13-28

19. Health, UDo, Human Services \%J Atlanta GCfDC, Prevention (2009): Fourth national report on human exposure to environmental chemicals

20. Health UDo, Services H (2018) Fourth national report on human exposure to environmental chemicals. Updated tables, March 2018, Volume One

21. Heitland P, Köster HD (2006) Biomonitoring of 30 trace elements in urine of children and adults by ICP-MS. Clin Chim Acta 365:310-318

22. Hoet $P$, Jacquerye C, Deumer G, Lison D, Haufroid V (2013) Reference values and upper reference limits for 26 trace elements in the urine of adults living in Belgium. Clinical chemistry and laboratory medicine 51, $839-49$

23. Ilmiawati C, Yoshida T, Itoh T, Nakagi Y, Saijo Y, Sugioka Y, Sakamoto M, Ikegami A, Ogawa M, Kayama F (2015) Biomonitoring of mercury, cadmium, and lead exposure in Japanese children: a cross-sectional study. Environ Health Prev Med 20:18-27

24. Kordas K, Queirolo El, Manay N, Peregalli F, Hsiao PY, Lu Y, Vahter M (2016) Low-level arsenic exposure: Nutritional and dietary predictors in first-grade Uruguayan children. Environmental research 147:16-23

25. Lewis RC, Meeker JD, Basu N, Gauthier AM, Cantoral A, Mercado-Garcia A, Peterson KE, Tellez-Rojo MM, Watkins DJ (2018) Urinary metal concentrations among mothers and children in a Mexico City birth cohort study. Int J Hyg Environ Health 221:609-615

26. Li Q, Cheng H, Zhou T, Lin C, Guo SJAE (2012) The estimated atmospheric lead emissions in China, 1990-2009. 60, 1-8

27. Miao X, Hao Y, Tang X, Xie Z, Liu L, Luo S, Huang Q, Zou S, Zhang C, Li J (2020) Analysis and health risk assessment of toxic and essential elements of the wild fish caught by anglers in Liuzhou as a large industrial city of China. Chemosphere 243:125337

28. Miao Y, Kong X, Li C (2018) Distribution, sources, and toxicity assessment of polycyclic aromatic hydrocarbons in surface soils of a heavy industrial city. Liuzhou China Environmental monitoring assessment 190:164

29. Molina-Villalba I, Lacasana M, Rodriguez-Barranco M, Hernandez AF, Gonzalez-Alzaga B, Aguilar-Garduno C, Gil F (2015) Biomonitoring of arsenic, cadmium, lead, manganese and mercury in urine and hair of children living near mining and industrial areas. Chemosphere 124:83-91

30. Nisse C, Tagne-Fotso R, Howsam M, Richeval C, Labat L, Leroyer A (2017) Blood and urinary levels of metals and metalloids in the general adult population of Northern France: The IMEPOGE study, 2008-2010. Int J Hyg Environ Health 220:341-363

31. Nordberg GF, Fowler BA, Nordberg M (2014) Handbook on the Toxicology of Metals. Academic press

32. Orisakwe OE, Otaraku JO (2013) Metal concentrations in cosmetics commonly used in Nigeria. TheScientificWorldJournal 2013,959637

33. Park C, Hwang M, Kim H, Ryu S, Lee K, Choi K, Paek D (2016) Early snapshot on exposure to environmental chemicals among Korean adults-results of the first Korean National Environmental Health Survey (2009-2011). Int J Hyg Environ Health 219:398-404

34. Perez R, Domenech E, Conchado A, Sanchez A, Coscolla C, Yusa V (2018) Influence of diet in urinary levels of metals in a biomonitoring study of a child population of the Valencian region (Spain). Sci Total Environ 618:1647-1657

35. Peter AL, Viraraghavan T (2005) Thallium: a review of public health and environmental concerns. Environment international 31:493-501

36. Pino A, Amato A, Alimonti A, Mattei D, Bocca B (2012) Human biomonitoring for metals in Italian urban adolescents: data from Latium Region. International journal of hygiene and environmental health 215, $185-90$

37. Riojas-Rodríguez H, Solís-Vivanco R, Schilmann A, Montes S, Rodríguez S, Ríos C, Rodríguez-Agudelo Y (2010) Intellectual function in Mexican children living in a mining area and environmentally exposed to manganese. Environmental health perspectives 118:1465-1470

Page $10 / 14$ 
38. Roca M, Sanchez A, Perez R, Pardo O, Yusa V (2016) Biomonitoring of 20 elements in urine of children. Levels and predictors of exposure. Chemosphere 144:1698-1705

39. Rocha GH, Steinbach C, Munhoz JR, Madia MA, Faria JK, Hoeltgebaum D, Barbosa F Jr, Batista BL, Souza VC, Nerilo SB, Bando E, Mossini SA, Nishiyama $\mathrm{P}$ (2016) Trace metal levels in serum and urine of a population in southern Brazil. Journal of trace elements in medicine and biology: organ of the Society for Minerals and Trace Elements (GMS) 35, 61 - 5

40. Saha N, Zaman MR (2013) Evaluation of possible health risks of heavy metals by consumption of foodstuffs available in the central market of Rajshahi City. Bangladesh Environmental monitoring assessment 185:3867-3878

41. Santos MD, Flores Soares MC, Martins Baisch PR, Muccillo Baisch AL, Rodrigues da Silva Junior FM (2018) Biomonitoring of trace elements in urine samples of children from a coal-mining region. Chemosphere 197:622-626

42. Schulz C, Angerer J, Ewers U, Kolossa-Gehring MJljoh, health e (2007): The German human biomonitoring commission. 210, 373-382

43. Schulz C, Angerer J, Ewers U, Heudorf U, Wilhelm M, Hygiene HBCotGFEAJIJo, Health E (2009) Revised and new reference values for environmental pollutants in urine or blood of children in Germany derived from the German environmental survey on children 2003-2006 (GerES IV). 212, 637-647

44. Schulz C, Wilhelm M, Heudorf U, Kolossa-Gehring M (2011) Update of the reference and HBM values derived by the German Human Biomonitoring Commission. Int J Hyg Environ Health 215:26-35

45. Singh P, Chowdhuri DKJMn (2017) Environmental presence of hexavalent but not trivalent chromium causes neurotoxicity in exposed Drosophila melanogaster. 54, 3368-3387

46. Sughis M, Nawrot TS, Riaz A, Ikram-Dar U, Mahmood A, Haufroid V, Nemery BJljoh, health e (2014): Metal exposure in schoolchildren and working children. A urinary biomonitoring study from Lahore, Pakistan. 217, 669-677

47. Tchounwou PB, Yedjou CG, Patlolla AK, Sutton DJ (2012) Heavy metal toxicity and the environment, Molecular, clinical and environmental toxicology. Springer, pp 133-164

48. Xu P, Wu L, Chen Y, Xu D, Wang X, Fu Q, Chen Z, Lou X, Lou J (2020) A cross-sectional study on school-age children living near a municipal waste incinerator: Urinary metal levels and renal impairment assessment. Chemosphere 241:125081

49. Zeinali T, Salmani F, Naseri K (2019) Dietary Intake of Cadmium, Chromium, Copper, Nickel, and Lead through the Consumption of Meat, Liver, and Kidney and Assessment of Human Health Risk in Birjand, Southeast of Iran. Biol Trace Elem Res 191:338-347

50. Zhang H, Mao Z, Huang K, Wang X, Cheng L, Zeng L, Zhou Y, Jing TJEi (2019) Multiple exposure pathways and health risk assessment of heavy metal (loid) $\mathrm{s}$ for children living in fourth-tier cities in Hubei Province. 129, 517-524

51. Zhang X, Cui X, Lin C, Ma J, Liu X, Zhu Y (2017) Reference levels and relationships of nine elements in first-spot morning urine and 24-h urine from 210 Chinese children. Int J Hyg Environ Health 220:227-234

52. Zhou J, Feng K, Li Y, Zhou YJES, Research P (2016) Factorial Kriging analysis and sources of heavy metals in soils of different land-use types in the Yangtze River Delta of Eastern China. 23, 14957-14967

\section{Figures}




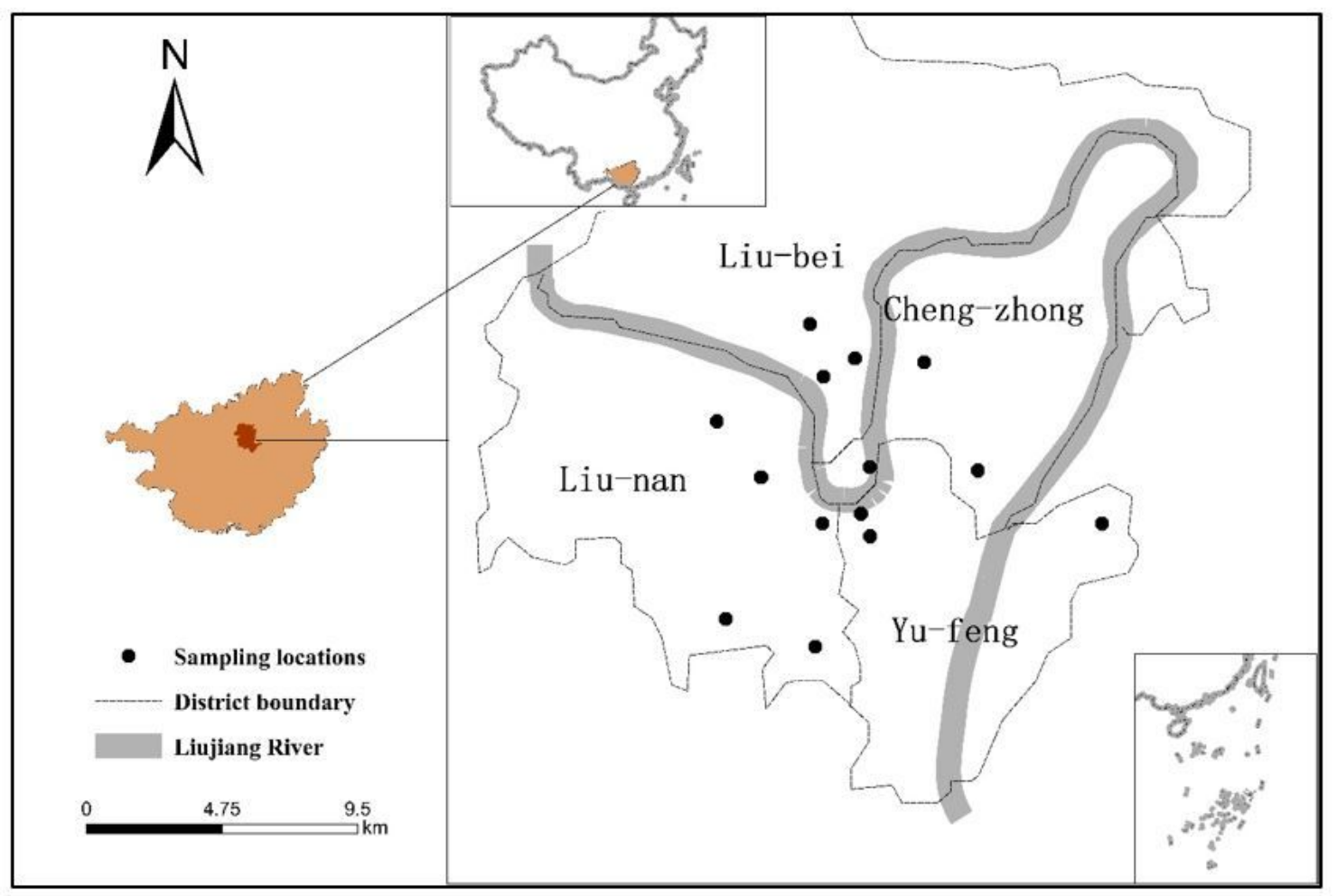

Figure 1

Location of study area Note: The designations employed and the presentation of the material on this map do not imply the expression of any opinion whatsoever on the part of Research Square concerning the legal status of any country, territory, city or area or of its authorities, or concerning the delimitation of its frontiers or boundaries. This map has been provided by the authors. 

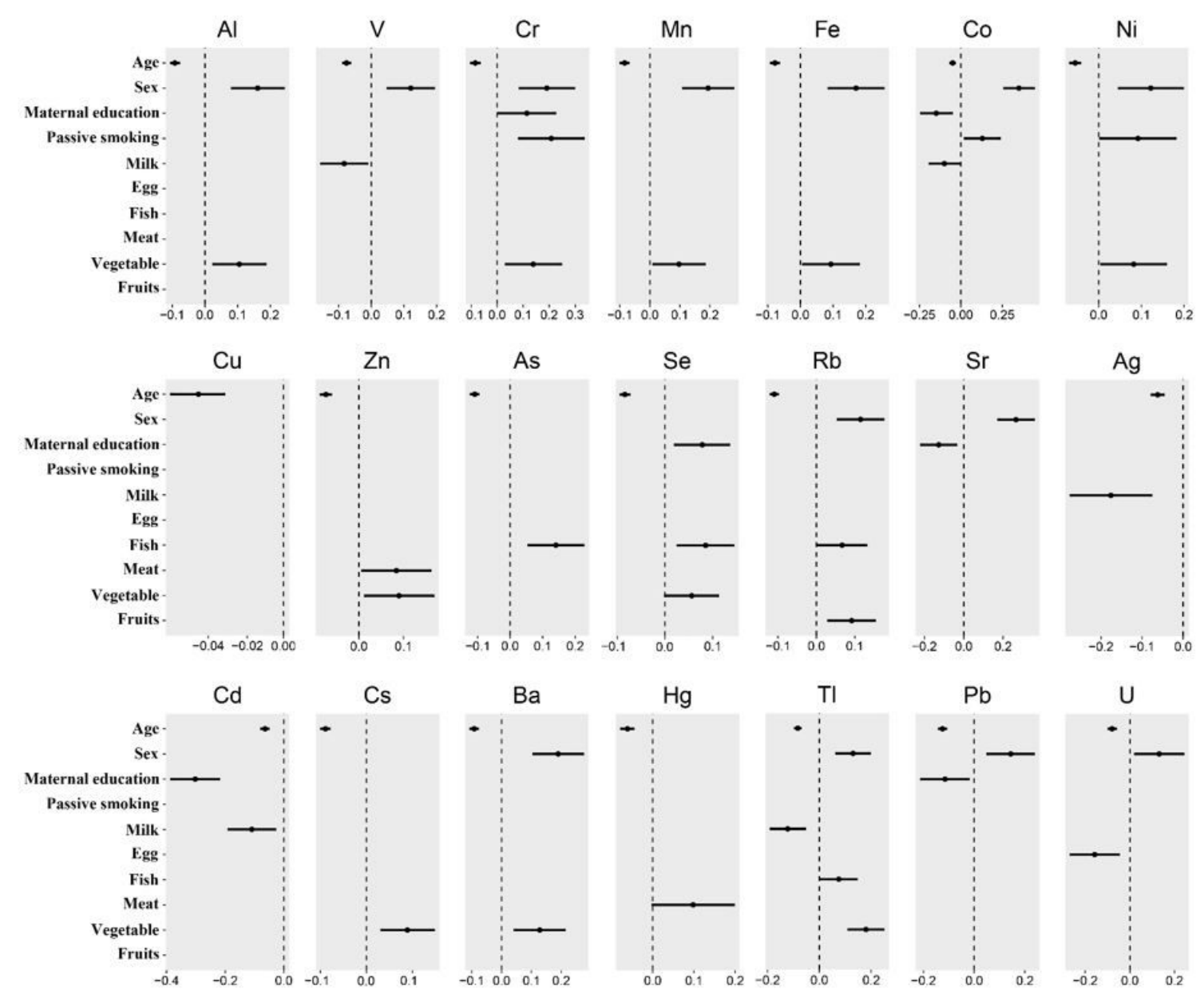

Beta and confidence interval

\section{Figure 2}

Beta and confidence intervals extracted from multivariate log-linear regression models for urinary metal(loid)s concentrations and potential predictors. 


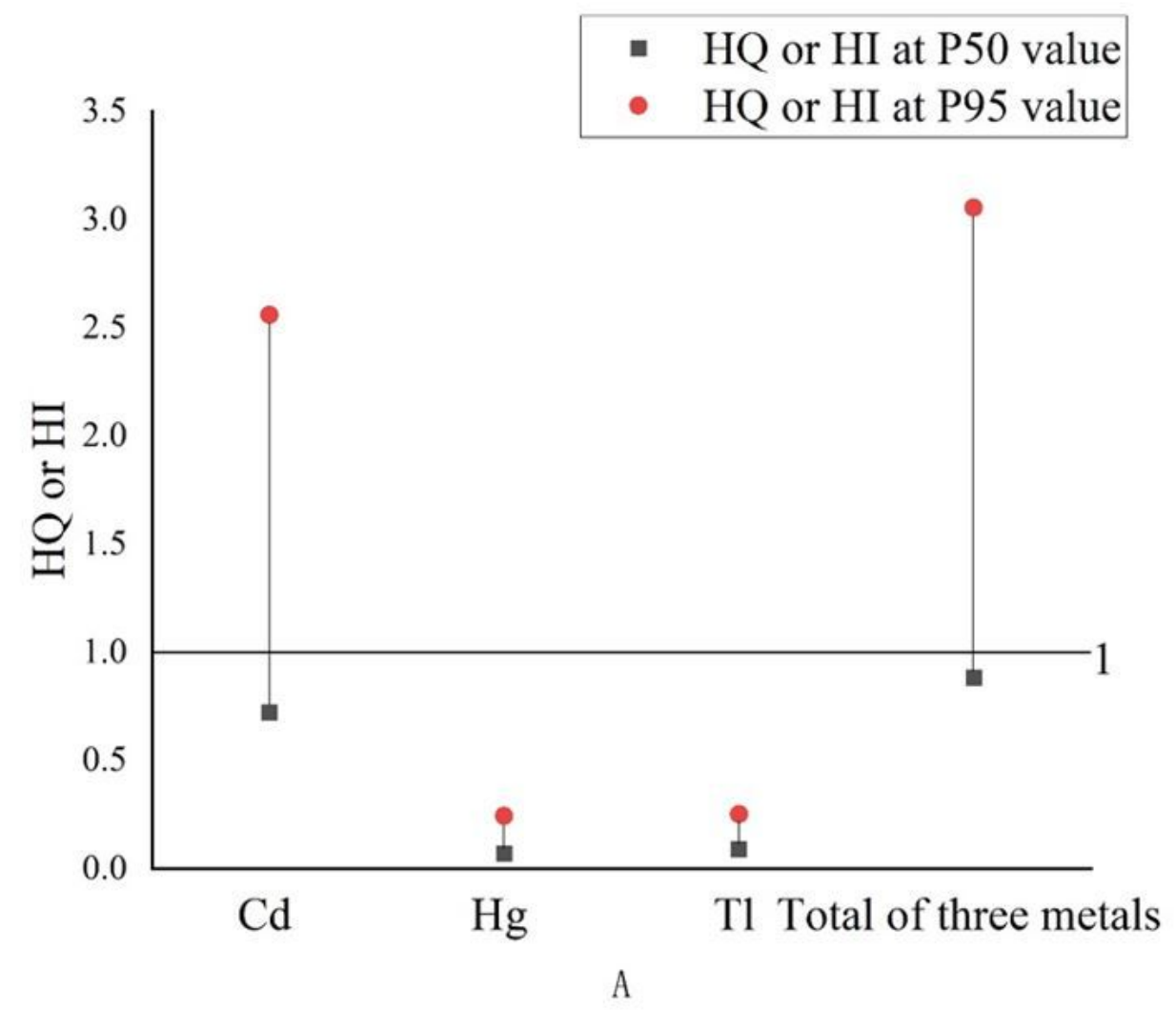

Figure 3

Hazard quotients (HQs) and hazard index $(\mathrm{HI})$ of metals

\section{Supplementary Files}

This is a list of supplementary files associated with this preprint. Click to download.

- supplementarydata.docx 